Article

\title{
Lipase Catalysed Kinetic Resolution of Racemic 1,2-Diols Containing a Chiral Quaternary Center
}

\author{
Gonzalo de Gonzalo \\ Departamento de Química Orgánica, Universidad de Sevilla, c/Profesor García González 1, 41012 Sevilla, Spain; \\ gdegonzalo@us.es; Tel.: +34-954559997
}

Received: 25 May 2018; Accepted: 27 June 2018; Published: 29 June 2018

check for updates

\begin{abstract}
Optically active 1,2-diols are valuable buildings blocks in organic synthesis. In the present paper, a set of racemic 1,2-diols with an ester functional group are prepared, starting from $\alpha$-ketoesters in a three-step procedure with moderate yields. The racemic 1,2-diols, containing a chiral quaternary center in their structure, are subjected to selective acylation in order to perform their kinetic resolution catalysed by a set of commercially available lipases. Under optimized reaction conditions, good conversions and enantioselectivities are achieved by using the lipase PSL-C from Pseudomonas cepacia in tert-butyl methyl ether. This biocatalyst could be reused up to five times without losing its properties.
\end{abstract}

Keywords: biocatalysis; lipases; kinetic resolution; 1,2-diols

\section{Introduction}

Optically active 1,2-diols are valuable compounds as they can be transformed into several interesting molecules [1-3]. Due to their importance as building blocks in organic synthesis, a number of synthetic methodologies have been developed for their preparation [4,5]. One of the most widely applied methods is Sharpless asymmetric dihydroxylation, which involves the oxidation of alkenes to form 1,2-diols in presence of chiral catalysts [6,7]. This methodology suffers some limitations including the relatively low activity and selectivity of the aromatic compounds and the substrate scope. For these reasons, different alternatives have been investigated. The use of biologically active systems as catalysts in organic reactions, including whole cells, cells free extracts, or purified enzymes, has emerged as a powerful tool for the preparation of high added value compounds under mild and environmentally friendly conditions [8-11].

The enzymes that have been used to catalyse the formation of chiral 1,2-diols belong to the oxidoreductases (alcohol dehydrogenases and dioxygenases) [12,13], and the hydrolases, including epoxide hydrolases [14,15] and lipases. This last group of enzymes (EC 3.1.1.3) have demonstrated their synthetic applicability, being the most used type of enzymes in industrial chemistry [16-18]. Lipases are widely available, have broad substrate acceptance and are able to catalyse reactions not only in aqueous mediums, but also in organic solvents, which expands their synthetic repertoire. In addition, lipases usually display a high degree of chemo-, regio- and/or enantioselectivity in the processes that they catalyse.

Lipases have been used to prepare optically active 1,2-diols catalysing the kinetic resolution of racemic mixtures in acylation reactions, thus leading to chiral diols and esters that can be converted back to the starting diols via hydrolysis [19-22]. In 2000, the kinetic resolution of racemic ethyl 2-benzyl-2,3-dihydroxypropanoate was described, a 1,2-diol containing an ester moiety precursor in the synthesis of $(S)$-etomoxir, which is a powerful hypoglucemic reagent [23]. After testing different biocatalysts, the lipase PS from Amano was found to catalyse the formation of (S)-1,2-diol and $(R)$-acetate with high selectivity and activity. Given this result, we decided to synthesise a set of 
functionalised 1,2-diols with an ester group and perform their kinetic resolution in the presence of different lipases, with the aim of obtaining these valuable optically active compounds.

\section{Results and Discussion}

\subsection{Preparation of the Racemic 1,2-Diols ( \pm -1-6d}

The racemic 1,2-diols were prepared in a three-step procedure starting from the corresponding $\alpha$-ketoesters 1-6a, as indicated in Table 1. These compounds were treated with N-tert-butyl formaldehyde hydrazone in toluene at room temperature to yield the racemic azocompounds $( \pm)-\mathbf{1}-\mathbf{6 b}$ with high yields (75-92\%) after $24 \mathrm{~h}$. For almost all the ketoesters, the reaction occurred in the absence of any catalyst, but for ethyl benzoylformate (1a), the addition was accelerated in the presence of the Schreiner's thiourea (I) at $10 \mathrm{~mol} \%$. The resulting azocompounds are valuable synthons that can be transformed in different compounds [24-26]. Their hydrolysis in a biphasic system $\mathrm{Et}_{2} \mathrm{O} / \mathrm{HCl}$ (aq) yielded the corresponding hydroxyaldehydes $( \pm$ )-1-6c after four hours via a tautomerization and hydrolysis process. Debt to their instability were directly reduced without purification to the racemic 1,2-diols $( \pm)$-1-6d by treatment with a mild reductant as tetrabutylammonium borohydride $\left(\mathrm{NBu}_{4} \mathrm{BH}_{4}\right)$ in $\mathrm{CH}_{2} \mathrm{Cl}_{2}$ at room temperature over two hours. Depending on the substrate structure, the 1,2-diols were obtained with yields from 41 to $57 \%$. Attempts to improve these yields by modifying certain reaction parameters as the hydrolysis conditions or the reducing agent were unsuccessful.

Table 1. Synthesis of racemic 1,2-diols $( \pm)-\mathbf{1}-\mathbf{6 d}$ in a three-step procedure starting from the commercially available $\alpha$-ketoesters 1-6a.

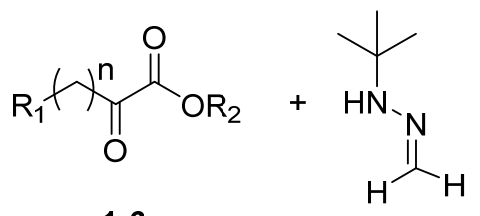

$1-6 a$

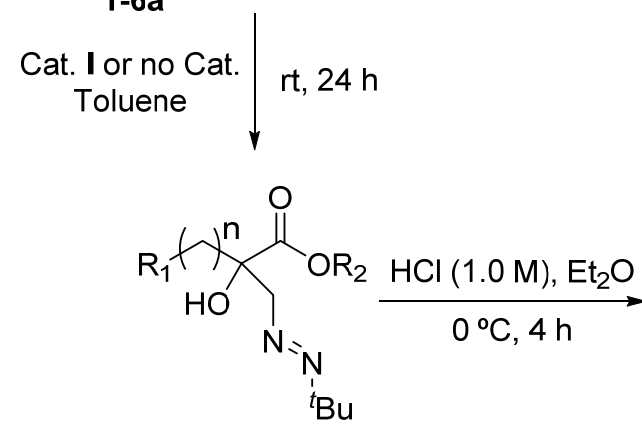

$( \pm)-1-6 b$

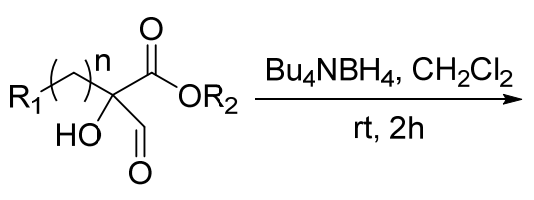

$( \pm)-1-6 c$<smiles>[R]OC(O)(O)C(=O)O</smiles>

$( \pm)-1-6 d$

\begin{tabular}{|c|c|c|c|c|c|}
\hline Entry & $\mathbf{R}_{1}$ & $\mathbf{R}_{2}$ & $\mathrm{n}$ & Yield $( \pm)-1-6 b^{a}$ & Yield $( \pm)-1-6 d^{a}$ \\
\hline 1 & $\mathrm{Ph}$ & Et & 0 & $( \pm)-\mathbf{1 b}, b^{b} 87$ & $( \pm)-\mathbf{1 d}, 47$ \\
\hline 2 & $\mathrm{Ph}$ & $\mathrm{Me}$ & 0 & $( \pm)-\mathbf{2 b}, 80$ & $( \pm)-\mathbf{2 d}, 49$ \\
\hline 3 & 4-CN-Ph & Et & 0 & $( \pm)-3 \mathbf{b}, 92$ & $( \pm)-3 d, 55$ \\
\hline 4 & 4-OMe-Ph & Et & 0 & $( \pm)-4 b, 85$ & $( \pm)-4 \mathrm{~d}, 45$ \\
\hline 5 & 2-Thiophenyl & Et & 0 & $( \pm)-5 \mathbf{b}, 90$ & $( \pm)-5 d, 41$ \\
\hline 6 & $\mathrm{H}$ & Et & 2 & $( \pm)-6 b, 85$ & $( \pm)-6 \mathrm{~d}, 57$ \\
\hline
\end{tabular}

${ }^{a}$ For reaction conditions, see Materials and Methods. ${ }^{b}$ Reaction performed with $10 \mathrm{~mol} \%$ of catalyst I.

\subsection{Kinetic Resolution of Racemic Diols ( \pm -1-1-6d}

Once the racemic 1,2-diols were synthesized, their kinetic resolution was performed. Our initial studies were performed using racemic ethyl 2,3-dihydroxy-2-phenylpropanoate $( \pm)-\mathbf{1 d}$ as the model substrate. The selective acetylation of this 1,2 -diol $(0.15 \mathrm{M})$ in toluene at $30^{\circ} \mathrm{C}$ was performed in 
presence of 3.0 equivalents of vinyl acetate to ensure an irreversible acylation process. The effects of different biocatalysts were analysed by screening several commercially available lipases, as indicated in Table 2. For all the biocatalysts tested, the $(R)$-enantiomer of the 1,2-diol was acetylated, yielding $(R)-1 \mathbf{e}$, whereas the (S)-1,2-diol remained unaltered. The use of immobilized Candida antarctica lipase B (CalB) resulted in a reaction without selectivity (entry 1 ), achieving a $23 \%$ conversion after four hours. When the reaction was catalysed by its isozyme A (entry 2), a more selective process was observed (enantioselectivity, $E=12$ ), demonstrating acylation slower than with CalB. As shown in entry 3, Pseudomonas cepacia lipase (PSL-C) seems to be the most suitable biocatalyst for this reaction, as a moderate $E$ value was obtained in a process with a $32 \%$ conversion after $20 \mathrm{~h}$, achieving $(R)-\mathbf{1 d}$ with $86 \%$ ee. The use of lipases from Pseudomonas fluorescens (PSF), Burkholderia sp. (BSL), Rhizopus oryzae, and Aspergillus oryzae led to very low enantioselectivities $(E<10$, entries $4-7)$, with conversions varying from $41 \%$ after $20 \mathrm{~h}$ with PSF, to 16\% with the same duration using the lipase from Aspergillus oryzae. The kinetic resolution catalysed by porcine pancreatic lipase (PPL) in toluene afforded a selectivity value of 13 , and a conversion close to $50 \%$ after $24 \mathrm{~h}$, as shown in entry 8 . The opposite lipase from Mucor miehei was not a suitable biocatalyst for this reaction, as only a $13 \%$ of $(R)$-1e was obtained after $24 \mathrm{~h}$ in a very low selective resolution (entry 9).

Table 2. Lipase-catalysed acylation of rac-ethyl 2,3-dihydroxy-2-phenylpropanoate (1d) at different reaction conditions.

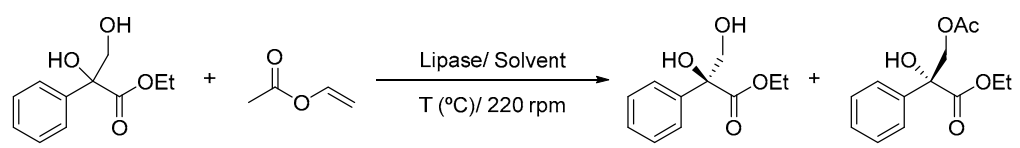

$( \pm)-1 d$

$(S)-1 d$

$(R)-1 \mathrm{e}$

\begin{tabular}{|c|c|c|c|c|c|c|c|c|}
\hline Entry & Lipase & Solvent & $\mathrm{T}\left({ }^{\circ} \mathrm{C}\right)$ & $t(h)$ & $c(\%)^{a}$ & $e e 1 \mathrm{~d}(\%)^{b}$ & $e e 1 \mathrm{e}(\%)^{\mathrm{c}}$ & $E^{\mathrm{d}}$ \\
\hline 1 & CalB & Toluene & 30 & 4 & 23 & 11 & 37 & 2 \\
\hline 2 & CalA & Toluene & 30 & 12 & 32 & 37 & 77 & 12 \\
\hline 3 & PSL-C & Toluene & 30 & 20 & 32 & 40 & 86 & 20 \\
\hline 4 & PSF & Toluene & 30 & 20 & 41 & 35 & 50 & 4 \\
\hline 5 & BSL & Toluene & 30 & 20 & 38 & 42 & 69 & 8 \\
\hline 6 & R. oryzae & Toluene & 30 & 20 & 23 & 22 & 75 & 9 \\
\hline 7 & A. oryzae & Toluene & 30 & 20 & 16 & 11 & 57 & 4 \\
\hline 8 & PPL & Toluene & 30 & 24 & 48 & 67 & 73 & 13 \\
\hline 9 & M. miehei & Toluene & 20 & 24 & 13 & 12 & 78 & 9 \\
\hline 10 & PSL-C & TBME & 30 & 12 & 42 & 62 & 91 & 41 \\
\hline 11 & CalA & TBME & 30 & 6 & 41 & 54 & 79 & 17 \\
\hline 12 & PPL & TBME & 30 & 12 & 38 & 50 & 77 & 13 \\
\hline 13 & PSL-C & 1,4-Dioxane & 30 & 20 & 23 & 25 & 86 & 17 \\
\hline 14 & PSL-C & $\mathrm{THF}$ & 30 & 20 & 6 & 6 & 87 & 15 \\
\hline 15 & PSL-C & DIPE & 30 & 12 & 45 & 67 & 83 & 22 \\
\hline 16 & PSL-C & TBME & 15 & 24 & 43 & 67 & 91 & 43 \\
\hline 17 & PSL-C ${ }^{\mathrm{e}}$ & TBME & 30 & 24 & 36 & 52 & 91 & 37 \\
\hline 18 & PSL-C $^{\mathrm{f}}$ & TBME & 30 & 48 & 34 & 47 & 91 & 34 \\
\hline
\end{tabular}

a Conversion, $c=e e_{\mathrm{s}} /\left(e e_{\mathrm{s}}+e e_{\mathrm{p}}\right)$. ${ }^{\mathrm{b}}$ Enantiomeric excesses were determined by high performance liquid chromatography (HPLC) after acetylation in presence of acetic anhydride in pyridine. ${ }^{c}$ Determined by HPLC.

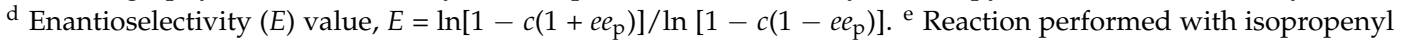
acetate as acyl donor. ${ }^{\mathrm{f}}$ Reaction performed with ethyl acetate as acyl donor.

After selecting PSL-C as the best biocatalyst for the acetylation of racemic 1d, we analysed other parameters that can affect the activity and selectivity of the biocatalyst. Thus, different organic solvents were tested in the acylation reaction. As shown in entry 10, tert-butyl methyl ether (TBME) was the best solvent for this process, as a good selectivity value could be achieved $(E=41)$ in a reaction much faster than in toluene (34\% conversion after eight hours with $91 \%$ ee for 1e). This solvent was also tested in the CalA-catalysed acylation, promoting an increase in both the enzyme activity and selectivity (entry 11). However, the $E$ value remained low. The reaction catalysed by PPL in TBME afforded the chiral acetate $(R)-1 e$ with $77 \%$ ee in a process with a 38\% conversion after $12 \mathrm{~h}$ (entry 12 ). Other solvents 
analysed in the acetylation catalysed by PSL-C, such as 1,4-dioxane or THF, led to slower resolutions and especially for the latter, whereas the enantioselectivities were around 15. The use of diisopropyl ether (DIPE) afforded (S)-1d with 67\% ee and (R)-1e with $83 \%$ ee in a process with a $45 \%$ conversion after $12 \mathrm{~h}$ (entry 15).

The effect of temperature was also analysed in this kinetic resolution, performing the PSL-C-catalysed reaction of $( \pm)-\mathbf{1 d}$ at $15{ }^{\circ} \mathrm{C}$, as shown in entry 16 . Lowering the temperature had no effect on the enzyme selectivity, whereas, as expected, the enzyme activity dropped ( $c=25 \%$ after $12 \mathrm{~h}$ ). The use of a less reactive acyl donor, such as isopropenyl acetate (entry 17), led to a similar selectivity. Chiral acetate $(R)-1 e$ was obtained with a 36\% conversion and $91 \%$ ee after $16 \mathrm{~h}$. When ethyl acetate was used as acyl donor (entry 17), a slower kinetic resolution was achieved, as $48 \mathrm{~h}$ were required to obtain a $34 \%$ yield of $(R)-1$ e with $91 \%$ ee (entry 18 ).

The recycling of the PSL-C was studied in the selective acetylation of $( \pm)-\mathbf{1 d}$ with vinyl acetate in TBME at $30^{\circ} \mathrm{C}$. After $20 \mathrm{~h}$, the biocatalyst was filtered, washed with TBME, and used again in a new reaction cycle. As shown in Figure 1, this biocatalyst could perform the selective acylation of the racemic diol for five cycles while maintaining its activity and selectivity. For the sixth reaction, a significant drop in the enantioselectivity of the process was observed $(E=27)$. For the seventh reaction, this drop was accompanied by an appreciable loss in enzymatic conversion.

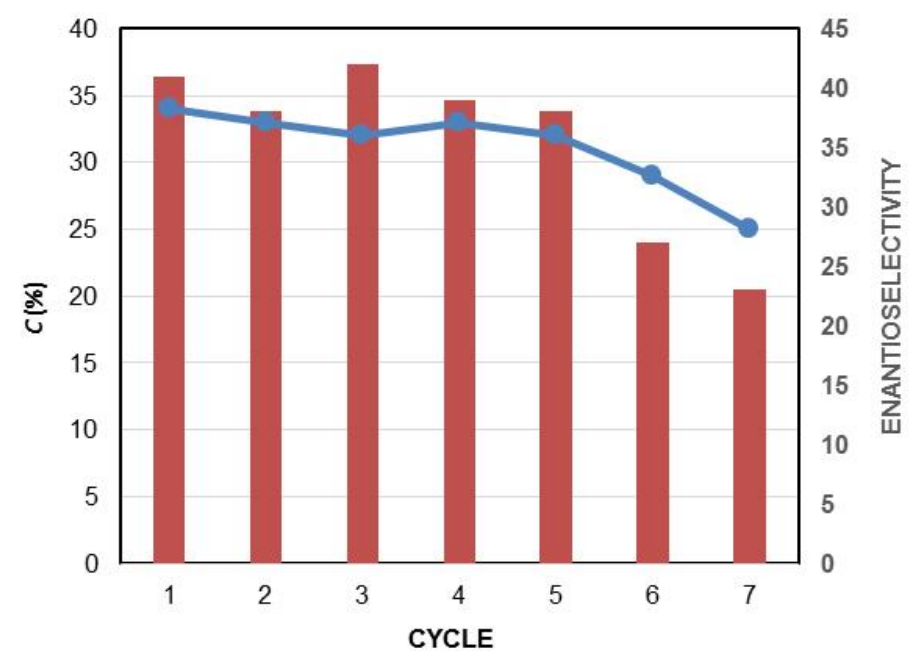

Figure 1. Effect of the PSL-C recycling on the conversion (blue line) and on the enantioselectivity (red bar) in the catalysed kinetic resolution of $\left( \pm\right.$ )-1d in tert-butyl methyl ether (TBME) at $30{ }^{\circ} \mathrm{C}$ using vinyl acetate as he acyl donor.

After the optimized conditions were set up for the kinetic resolution of racemic ethyl 2,3-dihydroxy-2-phenylpropanoate, using PSL-C and CalA in TBME at $30{ }^{\circ} \mathrm{C}$ and vinyl acetate as acyl donor, the scope of the reaction using different aromatic 1,2-diols was studied (Table 3). For all the aromatic substrates, $(R)$-acetates $\mathbf{2}-\mathbf{5 e}$ were the obtained products. The use of PSL-C led to higher enatioselectivities in all the aromatic and the heteroaromatic substrates (2-5a), whereas CalA showed higher activity. Thus, the enzymatic acylation of racemic methyl 2,3-dihydroxy-2-phenylpropanoate (2d) catalysed by PSL-C occurred with the same selectivity as for the ethyl analogue 1d ( $E=42$, entry 1 ) and with a higher conversion, achieving a $41 \%$ conversion after $12 \mathrm{~h}$. When the acylation was catalysed by CalA (entry 2) (R)-2e was obtained with $80 \%$ ee and a $42 \%$ conversion after eight hours $(E=16)$. The $p$-cyano derivative $( \pm)-3 c$ was a good substrate for both catalysts (entries 3 and 4 ). When using PSL-C, a $44 \%$ of $(R)-3 e$ with $90 \%$ ee was obtained after $12 \mathrm{~h}$, in a resolution with a good enantioselectivity value $(E=40)$, whereas the resolution catalysed by CalA led to a $47 \%$ conversion after eight hours and a good selectivity $(E=30)$. The presence of an electron-donating group in the aromatic ring of the diol seemed to have a negative effect on both the activity (41\% of $(R)-4 \mathbf{e}$ after 
$24 \mathrm{~h}$ ) and the selectivity ( $E=32$ ) of PSL-C (entry 3). This substrate was tested with CalA, but a low selectivity was observed $(E=11)$, in a kinetic resolution with a $36 \%$ conversion after $16 \mathrm{~h}$, as shown in entry 6. A heteroaromatic 1,2-diol as ( \pm -5d was successfully resolved by PSL-C in MTBE. After $24 \mathrm{~h}$, a $45 \%$ of $(R)-5$ e with $88 \%$ ee was achieved in a process with good selectivity, as shown in entry 7 . The use of CalA led to a $38 \%$ conversion after $16 \mathrm{~h}$ and moderate selectivity $(E=17$, entry 8$)$.

Table 3. PSL-C catalysed kinetic resolution of racemic diols 2-6d in tert-butyl methyl ether (TBME) at $30{ }^{\circ} \mathrm{C}$ using vinyl acetate as the acyl donor.

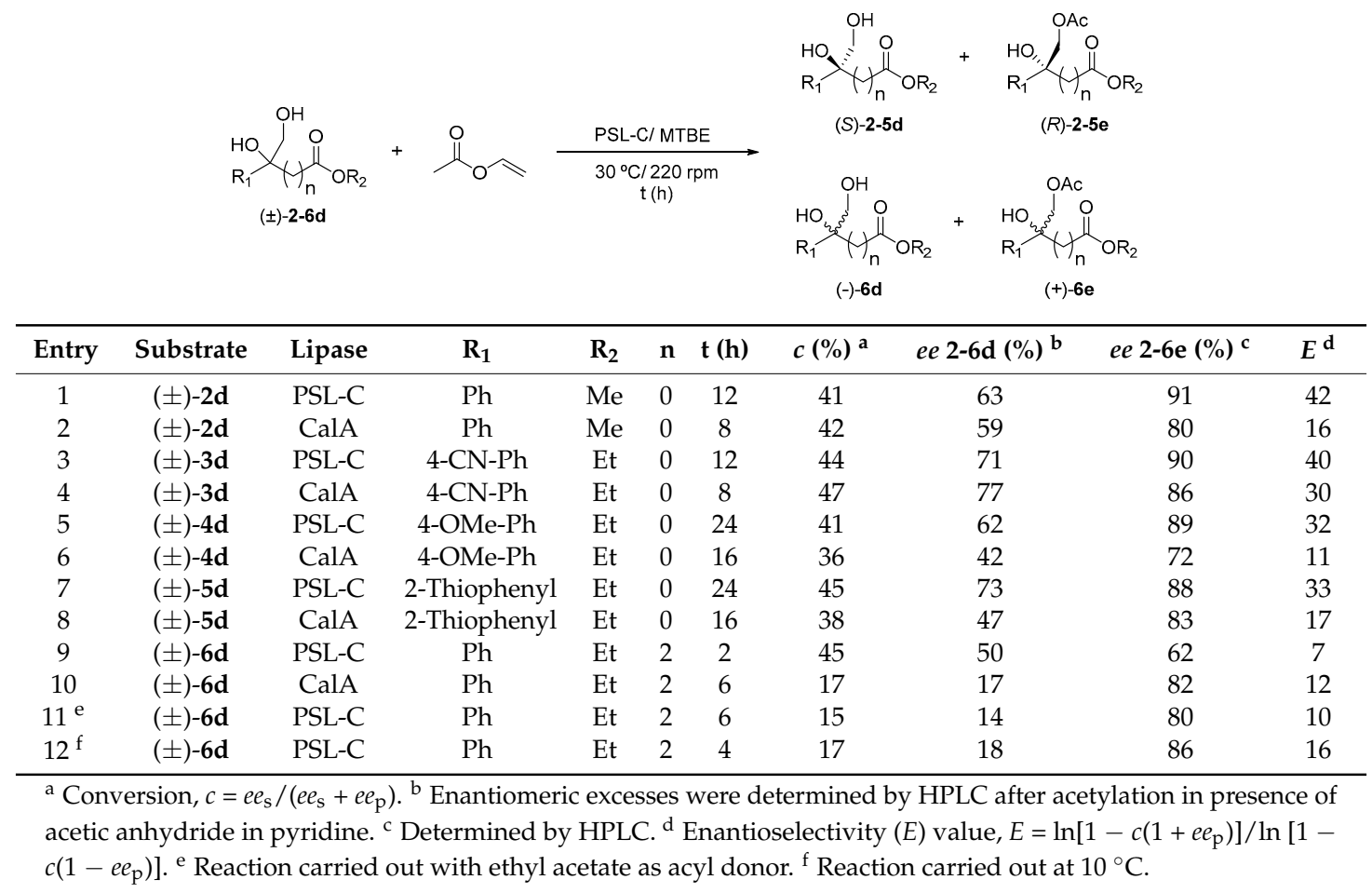

Regarding the aliphatic diol $( \pm)-6 \mathbf{d}$, in which the stereogenic center presents an aliphatic substituent, the enzymatic acylation in TBME at $30{ }^{\circ} \mathrm{C}$ using PSL-C afforded a very low enantioselectivity value $(E=7)$ in a very fast resolution, achieving a $45 \%$ of $(+)-6 e$ after $2 \mathrm{~h}$. In view of this result, the isozyme A from Candida antarctica was tested, leading to a slower ( $c=17 \%$ after $6 \mathrm{~h}$ ), but slightly more selective process $(E=12)$ than with PSL-C (see entry 10$)$. In order to improve the reaction selectivity, the PSL-C-catalysed resolutions were carried out using ethyl acetate as a less reactive acyl donor. After $6 \mathrm{~h}$, a 15\% of (+)-6e was obtained in a process with a low enantioselectivity $(E=10)$. Finally, the kinetic resolution in presence of vinyl acetate was conducted at $10^{\circ} \mathrm{C}$. After $4 \mathrm{~h}$, a $17 \%$ of diol $\mathbf{6 d}$ was converted into the acetate (+)-6e with $86 \% e e$, but the $E$ value was only increased to 16 (entry 12), indicating that this substrate was not appropriate for the biocatalysed acylation.

\section{Materials and Methods}

Unless otherwise noted, analytical grade solvents and commercially available reagents were used without further purification. Formaldehyde tert-butyl hydrazone [27] and organocatalyst I [28] were synthesized according to the literature. Racemic azocompounds $( \pm)-\mathbf{1 - 6 b}[24,26]$ and 1,2-diols $( \pm)$-1d and ( \pm -4,5d [29] exhibited the same physical and spectral properties as described in the bibliography and the nuclear magnetic resonance (NMR) data of the 1,2-diols are shown in the Supplementary Information. Pseudomonas cepacia lipase PSL-C (1638 U/g) and lipases from Pseudomonas fluorescens ( $\geq 160 \mathrm{U} / \mathrm{mg}$ ), Rhizopus oryzae ( $\geq 30 \mathrm{U} / \mathrm{mg})$, Aspergillus oryzae (ca. $50 \mathrm{U} / \mathrm{mg}$ ), Burkholderia sp. ( $\geq 160 \mathrm{U} / \mathrm{mg})$, porcine pancreatic $(\geq 20,000 \mathrm{U} / \mathrm{mg})$, and Mucor miehei $(\geq 4000 \mathrm{U} / \mathrm{mg})$ were purchased from Sigma-Aldrich (Saint Louis, MO, USA). Candida antarctica lipase type B (CalB, 
Novozyme 435, 7300 propyl laureate units per gram) was obtained from Novozymes (Bagsvaerd, Denmark). Candida antarctica lipase A (CalA) was obtained from Codexis (Redwood City, CA, USA).

NMR spectra were recorded in $\mathrm{CDCl}_{3}\left[{ }^{1} \mathrm{H}-\mathrm{NMR}(300 \mathrm{MHz}) ;{ }^{13} \mathrm{C}-\mathrm{NMR}(75.4 \mathrm{MHz})\right]$ with the solvent peak used as the internal reference (7.26 and $77.0 \mathrm{ppm}$ for ${ }^{1} \mathrm{H}$ and ${ }^{13} \mathrm{C}$, respectively). High-resolution mass spectrometry (HRMS) analyses were performed with an Orbitrap ELITE instrument (Waltham, ThermoFisher, MA, USA). Column chromatography was performed on silica gel (Merck Kieselgel 60, Kenilworth, NJ, USA). Analytical thin layer chromatography (TLC) was performed on aluminum backed plates $(1.5 \times 5.0 \mathrm{~cm})$ precoated $(0.25 \mathrm{~mm})$ with silica gel (Merck, Silica Gel 60 F254, Kenilworth, NJ, USA). The compounds were visualized by exposure to UV light or by dipping the plates into solutions of $\mathrm{KMnO}_{4}$ or vainilline stains followed by heating. HPLC analyses were performed on a Waters 2695 Instrument (Milford, MA, USA), equipped with a Waters 996 Photodiode Array Detector (Milford, MA, USA). To determine the enantiomeric excesses of diols (S)-1-6d and acetates (R)-1-6e, the following columns from Daicel (Tokyo, Japan) were employed: Chiralcel OD $(25 \times 0.46 \mathrm{~cm})$ and Chiralpak AD-H $(25 \times 0.46 \mathrm{~cm})$. The optical purity of the diols was measured after their derivatization to the corresponding acetates using acetic anhydride and pyridine in $\mathrm{CH}_{2} \mathrm{Cl}_{2}$. HPLC conditions and retention times are summarized in Table S1. The absolute configuration of the 1,2-diols (S)-1-5d and the acetates $(R)-\mathbf{1}-\mathbf{5 e}$ were established by comparison with the described values of the specific rotation for $(R)$-ethyl 2,3-dihydroxy-2-phenylpropanoate [ $(R)$-1d], (R)-ethyl 2,3-dihydroxy-2-(4-methoxyphenyl)propanoate $[(R)-4 \mathrm{~d}]$, and $(R)$-ethyl 2,3-dihydroxy-2-(tiophen-2-yl)propanoate, [(R)-5d] in reference [26].

\subsection{General Procedure for the Synthesis of Racemic Azocompounds ( \pm -1-1-6b}

The corresponding $\alpha$-ketoester 1-6a $(5.0 \mathrm{mmol})$ was dissolved at room temperature in toluene $(8.0 \mathrm{~mL})$ and $N$-tert-butyl formaldehyde hydrazone $(10 \mathrm{mmol})$ was added. For the ethyl benzoylformate, catalyst I ( $0.5 \mathrm{mmol}, 10 \mathrm{~mol} \%)$ was added prior to the hydrazone. Reactions were stirred at room temperature for $24 \mathrm{~h}$ until consumption of the starting material (TLC). The solvent was eliminated under reduced pressure and the obtained crudes were purified by column chromatography using toluene/EtOAc mixtures as the eluent in order to obtain the corresponding racemic azocompounds ( \pm )-1-6b with yields between 80 and $92 \%$.

\subsection{General Preparation of the Racemic 1,2-diols ( \pm -1-1-6d Starting from Azocompounds ( \pm )-1-6b}

The corresponding azocompound $( \pm)-\mathbf{1}-\mathbf{6 b}(4.0 \mathrm{mmol})$ was dissolved in $\mathrm{Et}_{2} \mathrm{O}(35 \mathrm{~mL})$, cooled to $0{ }^{\circ} \mathrm{C}$, and $\mathrm{HCl} 6.0 \mathrm{M}(15 \mathrm{~mL})$ was added. The reaction mixture was allowed to warm to room temperature and was stirred for $4 \mathrm{~h}$, and then extracted with $\mathrm{Et}_{2} \mathrm{O}(2 \times 15 \mathrm{~mL})$ and $\mathrm{CH}_{2} \mathrm{Cl}_{2}(2 \times 15 \mathrm{~mL})$. The organic layers were dried over $\mathrm{Na}_{2} \mathrm{SO}_{4}$ and the solvent was eliminated in vacuo to create the crude $\alpha$-hydroxyaldehydes $( \pm)$-1-6c, which were further reduced without purification. Tetrabutylamonium borohydride ( $560 \mathrm{mg}, 2.0 \mathrm{mmol}$ ) was added to a solution of the obtained aldehyde in $\mathrm{CH}_{2} \mathrm{Cl}_{2}(15 \mathrm{~mL})$ and the mixture was stirred at room temperature for $2 \mathrm{~h}$. After evaporation of the organic solvent, the crude was purified by column chromatography using $\mathrm{CH}_{2} \mathrm{Cl}_{2} / \mathrm{MeOH}$ 97:3 as the eluent, yielding the racemic 1,2-diols $( \pm$ )-1-6d (Figure 2).

( \pm )-Ethyl 2,3-dihydroxy-2-phenylpropanoate, $( \pm)$-1d: Yellow pale oil (395 $\mathrm{mg}$, yield 47\%). Spectroscopic data consistent with the literature [29].

( \pm )-Methyl 2,3-dihydroxy-2-phenylpropanoate, $( \pm$ )-2d: Yellow pale oil (384 mg, yield $49 \%) .{ }^{1} \mathrm{H}-\mathrm{NMR}$ $\left(300 \mathrm{MHz}, \mathrm{CDCl}_{3}\right): \delta(\mathrm{ppm}) 7.53\left(\mathrm{~d}, 2 \mathrm{H}, J=8.0 \mathrm{~Hz}, \mathrm{H}_{7}\right), 7.33-7.24\left(\mathrm{~m}, 3 \mathrm{H}, \mathrm{H}_{6}\right.$ and $\left.\mathrm{H}_{8}\right), 4.18(\mathrm{~d}, 1 \mathrm{H}$, $\left.J=10.8 \mathrm{~Hz}, \mathrm{H}_{3}\right), 4.13(\mathrm{bs}, 1 \mathrm{H}, \mathrm{OH}), 3.77\left(\mathrm{~s}, 3 \mathrm{H}, \mathrm{H}_{1}\right), 3.68\left(\mathrm{~d}, 1 \mathrm{H}, J=10.8 \mathrm{~Hz}, \mathrm{H}_{3^{\prime}}\right), 2.80(\mathrm{bs}, 1 \mathrm{H}, \mathrm{OH})$. ${ }^{13} \mathrm{C}-\mathrm{NMR}\left(75.4 \mathrm{MHz}, \mathrm{CDCl}_{3}\right): \delta(\mathrm{ppm}) 174.2\left(\mathrm{C}_{2}\right), 138.0\left(\mathrm{C}_{5}\right), 128.5\left(\mathrm{C}_{7}\right), 128.2\left(\mathrm{C}_{6}\right), 125.3\left(\mathrm{C}_{8}\right), 79.7\left(\mathrm{C}_{4}\right)$, $68.3\left(\mathrm{C}_{3}\right), 53.5\left(\mathrm{C}_{1}\right)$. HRMS: $m / z$ calcd. for $\mathrm{C}_{10} \mathrm{H}_{12} \mathrm{NaO}_{4}\left(\mathrm{M}+\mathrm{Na}^{+}\right)$: 219.02626; found: 219.02628.

( \pm )-Ethyl 2-(4-cyanophenyl)-2,3-dihydroxypropanoate, $( \pm$ )-3d: Colorless oil (517 $\mathrm{mg}$, yield 55\%).

${ }^{1} \mathrm{H}-\mathrm{NMR}\left(300 \mathrm{MHz}, \mathrm{CDCl}_{3}\right): \delta(\mathrm{ppm}) 7.69\left(\mathrm{~d}, 2 \mathrm{H}, J=8.5 \mathrm{~Hz}, \mathrm{H}_{8}\right), 7.59\left(\mathrm{~d}, 2 \mathrm{H}, J=8.5 \mathrm{~Hz}, \mathrm{H}_{7}\right), 4.29-4.21$ 
$\left(\mathrm{m}, 2 \mathrm{H}, \mathrm{H}_{2}\right), 4.15\left(\mathrm{~d}, 1 \mathrm{H}, J=11.4 \mathrm{~Hz}, \mathrm{H}_{5}\right), 4.07(\mathrm{bs}, 1 \mathrm{H}, \mathrm{OH}), 3.66\left(\mathrm{~d}, 1 \mathrm{H}, J=11.4 \mathrm{~Hz}, \mathrm{H}_{5^{\prime}}\right), 3.09$ (bs, $1 \mathrm{H}, \mathrm{OH}), 1.25\left(\mathrm{t}, 3 \mathrm{H}, J=7.1 \mathrm{~Hz}, \mathrm{H}_{1}\right) .{ }^{13} \mathrm{C}-\mathrm{NMR}\left(75.4 \mathrm{MHz}, \mathrm{CDCl}_{3}\right): \delta(\mathrm{ppm}) 172.6\left(\mathrm{C}_{3}\right), 143.2\left(\mathrm{C}_{6}\right)$, 132.2 $\left(\mathrm{C}_{8}\right), 126.6\left(\mathrm{C}_{7}\right), 118.5\left(\mathrm{C}_{10}\right), 112.3\left(\mathrm{C}_{9}\right), 79.4\left(\mathrm{C}_{4}\right), 68.2\left(\mathrm{C}_{5}\right), 63.3\left(\mathrm{C}_{2}\right), 14.0\left(\mathrm{C}_{1}\right)$. HRMS: $\mathrm{m} / \mathrm{z}$ calcd. for $\mathrm{C}_{12} \mathrm{H}_{13} \mathrm{NNaO}_{4}\left(\mathrm{M}+\mathrm{Na}^{+}\right)$: 258.0739; found: 258.0737 .

( \pm )-Ethyl 2,3-dihydroxy-2-(4-methoxyphenyl)propanoate, $( \pm)$-4d: Colorless oil (432 mg, yield 45\%). Spectroscopic data consistent with the literature [29].

( \pm )-Ethyl 2,3-dihydroxy-2-(tiophen-2-yl)propanoate, $( \pm)$-5d: White solid. m.p.: $76-78{ }^{\circ} \mathrm{C}(354 \mathrm{mg}$, yield $41 \%)$. Spectroscopic data consistent with the literature [29].

( \pm )-Ethyl 2-hydroxy-2-hydroxymethyl-4-phenylbutanoate, $( \pm$ )-6d: Colorless oil (384 mg, yield 57\%) ${ }^{1} \mathrm{H}-\mathrm{NMR}\left(300 \mathrm{MHz}, \mathrm{CDCl}_{3}\right): \delta(\mathrm{ppm}) 7.20-7.12\left(\mathrm{~m}, 2 \mathrm{H}, \mathrm{H}_{10}\right), 7.10-7.07\left(\mathrm{~m}, 3 \mathrm{H}, \mathrm{H}_{9}\right.$ and $\left.\mathrm{H}_{11}\right), 4.15(\mathrm{q}$, $\left.2 \mathrm{H}, J=7.0 \mathrm{~Hz}, \mathrm{H}_{2}\right), 3.98(\mathrm{~s}, \mathrm{OH}), 3.73\left(\mathrm{~d}, 1 \mathrm{H}, J=11.2 \mathrm{~Hz}, \mathrm{H}_{5}\right), 3.56\left(\mathrm{~d}, 1 \mathrm{H}, J=11.2 \mathrm{~Hz}, \mathrm{H}_{5^{\prime}}\right), 2.91(\mathrm{~s}$, $\mathrm{OH}), 2.78-2.68\left(\mathrm{~m}, 1 \mathrm{H}, \mathrm{H}_{6}\right), 2.43-2.33\left(\mathrm{~m}, 1 \mathrm{H}, \mathrm{H}_{6^{\prime}}\right), 1.98-1.78\left(\mathrm{~m}, 2 \mathrm{H}, \mathrm{H}_{7}\right), 1.22\left(\mathrm{t}, 3 \mathrm{H}, J=7.0 \mathrm{~Hz}, \mathrm{H}_{1}\right)$. ${ }^{13} \mathrm{C}-\mathrm{NMR}\left(75.4 \mathrm{MHz}, \mathrm{CDCl}_{3}\right): \delta(\mathrm{ppm}) 175.0\left(\mathrm{C}_{3}\right), 141.2\left(\mathrm{C}_{8}\right), 128.5\left(\mathrm{C}_{10}\right), 128.4\left(\mathrm{C}_{9}\right), 126.0\left(\mathrm{C}_{11}\right), 78.3$ $\left(\mathrm{C}_{4}\right), 68.0\left(\mathrm{C}_{5}\right), 62.4\left(\mathrm{C}_{2}\right), 36.6\left(\mathrm{C}_{6}\right), 29.5\left(\mathrm{C}_{7}\right), 14.2\left(\mathrm{C}_{1}\right)$. HRMS: $\mathrm{m} / \mathrm{z}$ calcd. for $\mathrm{C}_{13} \mathrm{H}_{18} \mathrm{NaO}_{4}\left(\mathrm{M}+\mathrm{Na}^{+}\right)$: 261.1102; found: 261.1097 .

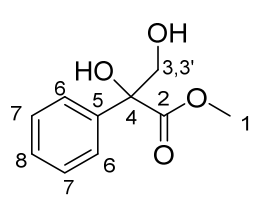

$( \pm)-2 d$

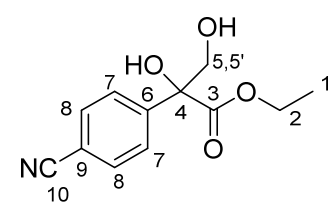

$( \pm)-3 d$

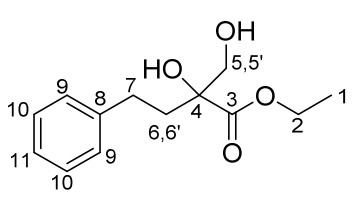

$( \pm)-6 d$

Figure 2. Structure and NMR assignation of the synthesized racemic 1,2-diols ( \pm )-2,3d and $\mathbf{6 d}$.

\subsection{General Synthesis of the Racemic Acetates ( \pm )-1-6e}

To a solution of the corresponding racemic 1,2-diol $( \pm)$-1-6d $(0.2 \mathrm{mmol})$ in $\mathrm{CH}_{2} \mathrm{Cl}_{2}(2.0 \mathrm{~mL})$, pyridine $(18 \mu \mathrm{L}, 0.22 \mathrm{mmol})$ and acetic anhydride $(20 \mu \mathrm{L}, 0.22 \mathrm{mmol})$ were added at room temperature. The reaction was stirred until disappearance of the starting material (TLC using hexane/EtOAc 7:3 as the eluent). The crude reaction was washed with $\mathrm{HCl} 1.0 \mathrm{~N}(2 \times 2.0 \mathrm{~mL})$, dried with $\mathrm{Na}_{2} \mathrm{SO}_{4}$, and the solvent was removed under reduced pressure to yield the corresponding racemic acetates $( \pm)-\mathbf{1 - 6 e}$, which were obtained after purification by column chromatography using $n$-hexane/EtOAc 7:3 as eluent (Figure 3).

( \pm )-Ethyl 3-acetoxy-2-hydroxy-2-phenylpropanoate, $( \pm)$-1e: Colorless oil (45.8 $\mathrm{mg}$, yield 91\%). ${ }^{1} \mathrm{H}-\mathrm{NMR}\left(300 \mathrm{MHz}, \mathrm{CDCl}_{3}\right): \delta(\mathrm{ppm}) 7.57-7.54\left(\mathrm{~m}, 2 \mathrm{H}, \mathrm{H}_{10}\right), 7.31-7.27\left(\mathrm{~m}, 3 \mathrm{H}, \mathrm{H}_{9}\right.$ and $\left.\mathrm{H}_{11}\right), 4.68-4.64$ $\left(\mathrm{d}, 1 \mathrm{H}, J=11.3 \mathrm{~Hz}, \mathrm{H}_{5}\right), 4.30-4.15\left(\mathrm{~m}, 3 \mathrm{H}, \mathrm{H}_{2}\right.$ and $\left.\mathrm{H}_{5^{\prime}}\right), 3.84(\mathrm{bs}, 1 \mathrm{H}, \mathrm{OH}), 2.00\left(\mathrm{~s}, 3 \mathrm{H}, \mathrm{H}_{7}\right), 1.22(\mathrm{t}$, $\left.3 \mathrm{H}, J=7.1 \mathrm{~Hz}, \mathrm{H}_{1}\right) ;{ }^{13} \mathrm{C}-\mathrm{NMR}\left(75.4 \mathrm{MHz}, \mathrm{CDCl}_{3}\right): \delta(\mathrm{ppm}) 172.8\left(\mathrm{C}_{6}\right) 170.6\left(\mathrm{C}_{3}\right), 137.6\left(\mathrm{C}_{8}\right), 129.3$ $\left(\mathrm{C}_{10}\right), 128.5\left(\mathrm{C}_{9}\right), 125.6\left(\mathrm{C}_{11}\right), 79.2\left(\mathrm{C}_{4}\right), 68.8\left(\mathrm{C}_{2}\right), 62.9\left(\mathrm{C}_{5}\right), 20.7\left(\mathrm{C}_{7}\right), 14.1\left(\mathrm{C}_{1}\right)$. HRMS: $\mathrm{m} / z$ calcd. for $\mathrm{C}_{13} \mathrm{H}_{16} \mathrm{NaO}_{5}\left(\mathrm{M}+\mathrm{Na}^{+}\right)$: 275.0892; found: 275.0890 .

( \pm )-Methyl 3-acetoxy-2-hydroxy-2-phenylpropanoate, $( \pm$ )-2e: Colorless oil (44.2 $\mathrm{mg}$, yield 93\%). ${ }^{1} \mathrm{H}-\mathrm{NMR}\left(300 \mathrm{MHz}, \mathrm{CDCl}_{3}\right): \delta(\mathrm{ppm}) \delta(\mathrm{ppm}) 7.55\left(\mathrm{~d}, 2 \mathrm{H}, J=8.2 \mathrm{~Hz}, \mathrm{H}_{9}\right), 7.31-7.27\left(\mathrm{~m}, 3 \mathrm{H}, \mathrm{H}_{8}\right.$ and $\left.\mathrm{H}_{10}\right), 4.64\left(\mathrm{~d}, 1 \mathrm{H}, J=11.2 \mathrm{~Hz}, \mathrm{H}_{4}\right), 4.31\left(\mathrm{~d}, 1 \mathrm{H}, J=11.2 \mathrm{~Hz}, \mathrm{H}_{4^{\prime}}\right), 3.77\left(\mathrm{~s}, 3 \mathrm{H}, \mathrm{H}_{1}\right), 2.54(\mathrm{bs}, 1 \mathrm{H}, \mathrm{OH}), 2.01$ $\left(\mathrm{s}, 3 \mathrm{H}, \mathrm{H}_{6}\right) .{ }^{13} \mathrm{C}-\mathrm{NMR}\left(75.4 \mathrm{MHz}, \mathrm{CDCl}_{3}\right): \delta(\mathrm{ppm}) 173.2\left(\mathrm{C}_{5}\right), 170.6\left(\mathrm{C}_{2}\right), 137.5\left(\mathrm{C}_{7}\right), 128.7\left(\mathrm{C}_{9}\right), 128.5$ $\left(\mathrm{C}_{8}\right), 125.6\left(\mathrm{C}_{10}\right), 77.6\left(\mathrm{C}_{3}\right), 68.8\left(\mathrm{C}_{4}\right), 53.5\left(\mathrm{C}_{1}\right), 20.8\left(\mathrm{C}_{6}\right)$. HRMS: $\mathrm{m} / z$ calcd. for $\mathrm{C}_{12} \mathrm{H}_{14} \mathrm{NaO}_{5}\left(\mathrm{M}+\mathrm{Na}^{+}\right)$: 261.0373; found: 261.0377 .

( \pm )-Ethyl 3-acetoxy-2-(4-cyanophenyl)-2-hydroxypropanoate, $( \pm)$-3e: Colorless oil (48.7 mg, yield $88 \%) .{ }^{1} \mathrm{H}-\mathrm{NMR}\left(300 \mathrm{MHz}, \mathrm{CDCl}_{3}\right): \delta(\mathrm{ppm}) 7.74-7.71\left(\mathrm{~d}, 2 \mathrm{H}, J=8.6 \mathrm{~Hz}, \mathrm{H}_{10}\right), 7.62-7.59(\mathrm{~d}, 2 \mathrm{H}$, $\left.J=8.6 \mathrm{~Hz}, \mathrm{H}_{9}\right), 4.61\left(\mathrm{~d}, 1 \mathrm{H}, J=11.3 \mathrm{~Hz}, \mathrm{H}_{5}\right), 4.31-4.17\left(\mathrm{~m}, 3 \mathrm{H}, \mathrm{H}_{2}\right.$ and $\left.\mathrm{H}_{5^{\prime}}\right), 4.01(\mathrm{bs}, 1 \mathrm{H}, \mathrm{OH}), 2.00$ 
$\left(\mathrm{s}, 3 \mathrm{H}, \mathrm{H}_{7}\right), 1.23\left(\mathrm{t}, 3 \mathrm{H}, J=7.1 \mathrm{~Hz}, \mathrm{H}_{1}\right) .{ }^{13} \mathrm{C}-\mathrm{NMR}\left(75.4 \mathrm{MHz}, \mathrm{CDCl}_{3}\right): \delta(\mathrm{ppm}) 171.7\left(\mathrm{C}_{6}\right), 170.4\left(\mathrm{C}_{3}\right)$, $141.0\left(C_{8}\right), 132.2\left(C_{10}\right), 126.8\left(C_{9}\right), 119.0\left(C_{12}\right), 112.5\left(C_{11}\right), 77.3\left(C_{4}\right), 68.5\left(C_{5}\right), 63.5\left(C_{2}\right), 20.7\left(C_{7}\right), 14.0$ $\left(\mathrm{C}_{1}\right)$.HRMS: $\mathrm{m} / z$ calcd. for $\mathrm{C}_{14} \mathrm{H}_{15} \mathrm{NNaO}_{5}\left(\mathrm{M}+\mathrm{Na}^{+}\right)$: 300.0842; found: 300.0849 .

$( \pm)$-Ethyl 3-acetoxy-2-hydroxy-2-(4-methoxyphenyl)propanoate, $( \pm)$-4e: Colorless oil (50.8 mg, yield 90\%). ${ }^{1} \mathrm{H}-\mathrm{NMR}\left(300 \mathrm{MHz}, \mathrm{CDCl}_{3}\right): \delta(\mathrm{ppm}) 7.47\left(\mathrm{~d}, 2 \mathrm{H}, J=8.1 \mathrm{~Hz}, \mathrm{H}_{9}\right), 6.91\left(\mathrm{~d}, 2 \mathrm{H}, J=8.1 \mathrm{~Hz}, \mathrm{H}_{10}\right)$, $4.58\left(\mathrm{~d}, 1 \mathrm{H}, J=11.0 \mathrm{~Hz}, \mathrm{H}_{5}\right), 4.30-4.15\left(\mathrm{~m}, 3 \mathrm{H}, \mathrm{H}_{2}\right.$ and $\left.\mathrm{H}_{5^{\prime}}\right), 3.97(\mathrm{bs}, 1 \mathrm{H}, \mathrm{OH}), 2.03\left(\mathrm{~s}, 3 \mathrm{H}, \mathrm{H}_{7}\right), 1.30(\mathrm{t}$, $\left.3 \mathrm{H}, J=7.0 \mathrm{~Hz}, \mathrm{H}_{1}\right) .{ }^{13} \mathrm{C}-\mathrm{NMR}\left(75.4 \mathrm{MHz}, \mathrm{CDCl}_{3}\right): \delta(\mathrm{ppm}) 171.8\left(\mathrm{C}_{6}\right), 169.7\left(\mathrm{C}_{3}\right), 158.0\left(\mathrm{C}_{11}\right), 131.1\left(\mathrm{C}_{8}\right)$, 127.2 $\left(\mathrm{C}_{9}\right), 111.0\left(\mathrm{C}_{10}\right), 79.3\left(\mathrm{C}_{4}\right), 68.0\left(\mathrm{C}_{5}\right), 63.0\left(\mathrm{C}_{2}\right), 57.2\left(\mathrm{C}_{12}\right), 21.2\left(\mathrm{C}_{7}\right), 14.0\left(\mathrm{C}_{1}\right)$. HRMS: $\mathrm{m} / \mathrm{z}$ calcd. for $\mathrm{C}_{14} \mathrm{H}_{18} \mathrm{O}_{6}\left(\mathrm{M}^{+}\right)$282.1103; found: 282.1098 .

( \pm )-Ethyl 3-acetoxy-2-hydroxy-2-(tiophen-2-yl)propanoate, $( \pm)$-5e: Yellow pale oil (41.4 mg, yield $81 \%) .{ }^{1} \mathrm{H}-\mathrm{NMR}\left(300 \mathrm{MHz}, \mathrm{CDCl}_{3}\right): \delta(\mathrm{ppm}) 7.25\left(\mathrm{dd}, 1 \mathrm{H}, J=5.1,1.3 \mathrm{~Hz}, \mathrm{H}_{11}\right), 7.10(\mathrm{dd}, 1 \mathrm{H}, J=3.7$, $\left.1.3 \mathrm{~Hz}, \mathrm{H}_{10}\right), 6.98\left(\mathrm{dd}, 1 \mathrm{H}, J=5.1,3.7 \mathrm{~Hz}, \mathrm{H}_{9}\right), 4.56\left(\mathrm{~d}, 1 \mathrm{H}, J=11.1 \mathrm{~Hz}, \mathrm{H}_{5}\right), 4.33-4.19\left(\mathrm{~m}, 3 \mathrm{H}, \mathrm{H}_{2}\right.$ and $\left.\mathrm{H}_{5^{\prime}}\right), 2.91(\mathrm{bs}, 1 \mathrm{H}, \mathrm{OH}), 2.00\left(\mathrm{~s}, 3 \mathrm{H}, \mathrm{H}_{7}\right), 1.25(\mathrm{t}, 3 \mathrm{H}, J=7.0 \mathrm{~Hz}, \mathrm{H1}) .{ }^{13} \mathrm{C}-\mathrm{NMR}\left(75.4 \mathrm{MHz}, \mathrm{CDCl}_{3}\right): \delta$ (ppm) $171.8\left(\mathrm{C}_{6}\right), 170.3\left(\mathrm{C}_{3}\right), 141.7\left(\mathrm{C}_{8}\right), 127.2\left(\mathrm{C}_{11}\right), 125.9\left(\mathrm{C}_{10}\right), 125.0\left(\mathrm{C}_{9}\right), 76.4\left(\mathrm{C}_{4}\right), 69.2\left(\mathrm{C}_{5}\right), 63.2\left(\mathrm{C}_{2}\right)$, $20.7\left(\mathrm{C}_{7}\right), 13.9\left(\mathrm{C}_{1}\right)$. HRMS: calcd. for $\mathrm{C}_{11} \mathrm{H}_{14} \mathrm{NaO}_{4} \mathrm{~S}\left(\mathrm{M}+\mathrm{Na}^{+}\right)$: 281.0456; found: 281.0454 .

$( \pm$ )-Ethyl 2-(acetoxymethyl)-2-hydroxy-4-phenylbutanoate, $( \pm$ )-6e: Colorless oil (47.6 mg, yield 85\%). ${ }^{1} \mathrm{H}-\mathrm{NMR}\left(300 \mathrm{MHz}, \mathrm{CDCl}_{3}\right): \delta(\mathrm{ppm}) 7.21-7.18\left(\mathrm{~m}, 2 \mathrm{H}, \mathrm{H}_{12}\right), 7.13-7.07\left(\mathrm{~m}, 3 \mathrm{H}, \mathrm{H}_{11}\right.$ and $\left.\mathrm{H}_{13}\right), 4.19-4.08$ (m $4 \mathrm{H}, \mathrm{H}_{2}, \mathrm{H}_{5}$ and $\left.\mathrm{H}_{5^{\prime}}\right), 3.51(\mathrm{bs}, 1 \mathrm{H}, \mathrm{OH}), 2.79-2.70\left(\mathrm{~m}, 1 \mathrm{H}, \mathrm{H}_{8}\right), 2.45-2.35\left(\mathrm{~m}, 1 \mathrm{H}, \mathrm{H}_{8^{\prime}}\right), 1.99-1.90(\mathrm{~m}$, $5 \mathrm{H}, \mathrm{H}_{7}$ and $\left.\mathrm{H}_{9}\right), 1.21\left(\mathrm{t}, 3 \mathrm{H}, J=7.1 \mathrm{~Hz}, \mathrm{H}_{1}\right) .{ }^{13} \mathrm{C}-\mathrm{NMR}\left(75.4 \mathrm{MHz}, \mathrm{CDCl}_{3}\right): \delta(\mathrm{ppm}) 173.9\left(\mathrm{C}_{6}\right), 170.5$ $\left(C_{3}\right), 141.0\left(C_{10}\right), 128.4\left(C_{11}\right), 126.1\left(C_{12}\right), 125.7\left(C_{13}\right), 76.0\left(C_{4}\right), 68.9\left(C_{5}\right), 62.4\left(C_{2}\right), 36.8\left(C_{8}\right), 29.3\left(C_{9}\right)$, $20.7\left(\mathrm{C}_{7}\right), 14.2\left(\mathrm{C}_{1}\right)$. HRMS: $\mathrm{m} / z$ calcd. for $\mathrm{C}_{15} \mathrm{H}_{20} \mathrm{NaO}_{5}\left(\mathrm{M}^{+}\right)$: 303.1204; found: 303.1203 .

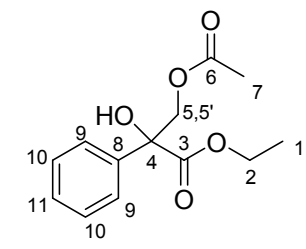

$( \pm)-1 e$

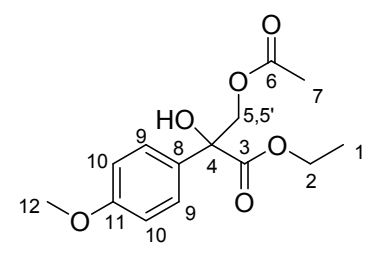

$( \pm)-4 e$

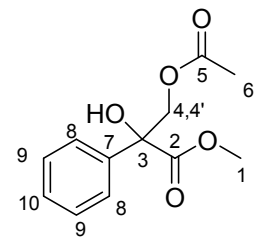

$( \pm)-2 e$

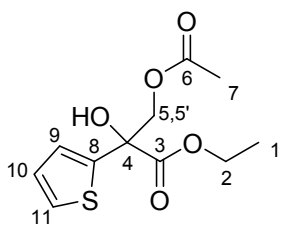

$( \pm)-5 e$

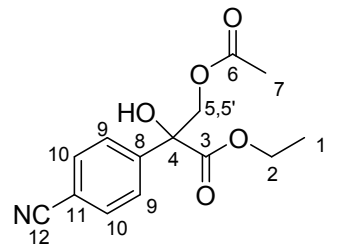

$( \pm)-3 e$

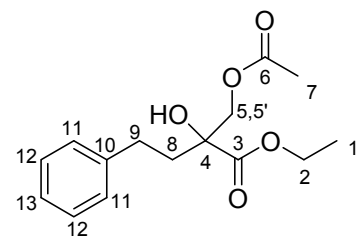

(土)-6e

Figure 3. Structure and NMR assignation of the synthesized racemic acetates $( \pm)-\mathbf{1 - 6 e}$.

\subsection{General Procedure for the Biocatalyzed Acylation of the Racemic 1,2-diols ( \pm )-1-6d}

Unless otherwise stated, vinyl acetate $(0.9 \mathrm{mmol})$ was added to a solution of the racemic diol $( \pm)-\mathbf{1}-6 \mathrm{~d}(0.3 \mathrm{mmol})$ in TBME $(2.0 \mathrm{~mL})$ containing the PSL-C $(30 \mathrm{mg})$ and $\mathrm{Na}_{2} \mathrm{CO}_{3}(0.25 \mathrm{mmol})$. Reactions were stirred at $30^{\circ} \mathrm{C}$ at $220 \mathrm{rpm}$ and monitored by TLC using $n$-hexane/EtOAc 7:3 as the eluent. Once finished, the lipase was filtered, washed with TBME $(2 \times 2 \mathrm{~mL})$, and the solvent was evaporated under reduced pressure. The crude mixture was purified by column chromatography using $n$-hexane/EtOAc 7:3 as the eluent in order to obtain the (S)-1,2-diols 1-6d and the $(R)$-acetates 1-6e, which were analysed by HPLC at the conditions described in Table S1 for the determination of the optical purities. (S)-1d: $37.8 \mathrm{mg}, 60 \%$ yield; $[\alpha]_{\mathrm{D}}^{21}=-2.9\left(c=0.6, \mathrm{CHCl}_{3}, 47 \%\right.$ ee $)$; $(R)-1 \mathrm{e}: 23.0$ $\mathrm{mg}, 32 \%$ yield; $[\alpha]_{\mathrm{D}}^{21}=+10.8\left(c=1.0, \mathrm{CHCl}_{3}, 92 \% e e\right) .(S)-2 \mathrm{~d}: 33.8 \mathrm{mg}, 57 \%$ yield; $[\alpha]_{\mathrm{D}}^{21}=-3.8(c=0.5$, 
$\left.\mathrm{CHCl}_{3}, 55 \% e e\right)$; (R)-2e: $24.1 \mathrm{mg}, 35 \%$ yield; $[\alpha]_{\mathrm{D}}^{21}=+12.1\left(c=0.8, \mathrm{CHCl}_{3}, 92 \% e e\right)$. (S)-3d: $50.5 \mathrm{mg}, 71 \%$ yield; $[\alpha]_{\mathrm{D}}^{21}=-4.2\left(c=1.0, \mathrm{CHCl}_{3}, 32 \% e e\right) ;(R)-3 \mathrm{e}: 19.4 \mathrm{mg}, 22 \%$ yield; $[\alpha]_{\mathrm{D}}^{21}=+9.8\left(c=1.2, \mathrm{CHCl}_{3}, 93 \%\right.$ ee). (S)-4d: $51.6 \mathrm{mg}, 72 \%$ yield; $[\alpha]_{D}^{21}=-1.7\left(c=0.4, \mathrm{CHCl}_{3}, 30 \% e e\right) ;(R)-4 \mathrm{e}: 16.9 \mathrm{mg}, 20 \%$ yield; $[\alpha]_{D}^{21}=$ $+6.8\left(c=1.2, \mathrm{CHCl}_{3}, 92 \% e e\right) .(S)-5 \mathrm{~d}: 38.1 \mathrm{mg}, 59 \%$ yield; $[\alpha]_{\mathrm{D}}^{21}=-2.7\left(c=0.75, \mathrm{CHCl}_{3}, 50 \% e e\right) ;(R)-5 \mathrm{e}$ : $23.2 \mathrm{mg}, 30 \%$ yield; $[\alpha]_{\mathrm{D}}^{21}=+10.2\left(c=1.05, \mathrm{CHCl}_{3}, 90 \% e e\right) .(-)-6 \mathrm{~d}: 34.0 \mathrm{mg}, 48 \%$ yield; $[\alpha]_{\mathrm{D}}^{21}=-3.8$ $\left(c=0.5, \mathrm{CHCl}_{3}, 50 \% e e\right)$; and (+)-6e: $33.6 \mathrm{mg}, 40 \%$ yield, $[\alpha]_{\mathrm{D}}^{21}=+5.6\left(c=1.2, \mathrm{CHCl}_{3}, 62 \% e e\right)$.

\section{Conclusions}

A set of aromatic and non-aromatic 1,2-diols containing an ester moiety were prepared in a three-step procedure with moderate yields from the corresponding $\alpha$-ketoesters. These functionalized racemic 1,2-diols were tested in lipase-catalysed acetylations. After optimization of the reaction conditions, we achieved good activities and selectivities in the resolution of aromatic 1,2-diols by employing the Pseudomonas cepacia lipase (PSL-C) in tert-butyl methyl ether as the solvent. This biocatalyst showed a higher selectivity for the preparation of chiral (S)-1,2-diols and $(R)$-acetates containing unsubstituted aromatic rings or presenting electron-withdrawing groups, whereas the reactions were slower and slightly less selective for aromatic substrates with electron-donating groups or heteroaromatic systems. PSL-C could be recycled for five reactions without appreciable loss in its biocatalytic properties, thus resulting in a promising biocatalyst for the preparation of optically active 1,2-diols.

Supplementary Materials: The following are available online at http:/ /www.mdpi.com/1420-3049/23/7/1585/ s1, Table S1: HPLC analyses; and assignment of ${ }^{1} \mathrm{H}$ and ${ }^{13} \mathrm{C}-\mathrm{NMR}$ of synthesized compounds.

Funding: This research received no external funding.

Acknowledgments: This work was supported by the Ministerio de Economía y Competitividad, MINECO (contract RYC-2012-10014 for G.d.G., Grants CTQ2016-76908-C2-1-P and CTQ2016-76908-C2-2-P), the European FEDER Funds, and the Junta de Andalucía (Grant 2012/FQM 10787).

Conflicts of Interest: Author declares no conflict of interest.

\section{References}

1. Werner, L.; Machara, A.; Hudlicky, T. Short chemoenzymatic azide-free synthesis of oseltamivir (Tamiflu): Approaching the potential for process efficiency. Adv. Synth. Catal. 2010, 352, 195-200. [CrossRef]

2. Wu, X.; Wang, L.; Wang, S.; Chen, Y. Stereoselective introduction of two chiral centers by a single diketoreductase: An efficient biocatalytic route for the synthesis of statin side chains. Amino Acids 2010, 39, 305-308. [CrossRef] [PubMed]

3. Omori, A.T.; Finn, K.J.; Leisch, H.; Carroll, R.J.; Hudlicky, T. Chemoenzymatic total synthesis of (+)-codeine by sequential intramolecular Heck cyclizations via C-B-D ring construction. Synlett 2007, 18, 2859-2862.

4. Kanicha, S.; Montgomery, J. Highly diastereoselective preparation of anti-1,2-diols by catalytic addition of alkynylsilanes to $\alpha$-silyloxyaldehydes. Org. Lett. 2006, 8, 4441-4443.

5. Bataille, C.J.R.; Donohoe, T.J. Osmium-free direct syn-dihydroxylation of alkenes. Chem. Soc. Rev. 2011, 40, 114-128. [CrossRef] [PubMed]

6. Sharpless, K.B.; Akashi, K. Osmium catalyzed vicinal hydroxylation of olefins by tert-butyl hydroperoxide under alkaline conditions. J. Am. Chem. Soc. 1976, 98, 1986-1987. [CrossRef]

7. Andersson, M.A.; Epple, R.; Fokin, V.V.; Sharpless, K.B. A new approach to osmium-catalyzed asymmetric dihydroxylation and aminohydroxylation of olefins. Angew. Chem. Int. Ed. 2002, 41, 472-475. [CrossRef]

8. De Gonzalo, G.; Domínguez de María, P. Biocatalysis: An Industrial Perspective, 1st ed.; Royal Society of Chemistry: Cambridge, UK, 2017; ISBN 978-1-78262-619-0.

9. Sheldon, R.A.; Woodley, J.M. Role of biocatalysis in sustainable chemistry. Chem. Rev. 2018, 118, 801-838. [CrossRef] [PubMed]

10. Patel, R.N. Green Biocatalysis, 1st ed.; John Wiley \& Sons: Hoboken, NJ, USA, 2016; ISBN 978-1-118-82229-6.

11. Hudlicky, T.; Reed, J.W. Application of biotransformations and biocatalysis to complexity generation in organic synthesis. Chem. Soc. Rev. 2009, 38, 3117-3132. [CrossRef] [PubMed] 
12. Boyd, D.R.; Sharma, N.D.; Bowers, N.I.; Brannigan, I.N.; Groocock, M.R.; Malone, J.E.; McConville, G.; Allen, C.C.R. Biocatalytic asymmetric dihydroxylation of conjugated mono- and poly-alkenes to yield enantiopure cyclic cis-diols. Adv. Synth. Catal. 2005, 347, 1081-1089. [CrossRef]

13. Chen, Y.; Chen, C.; Wu, X. Dicarbonyl reduction by single enzyme for the preparation of chiral diols. Chem. Soc. Rev. 2012, 41, 1742-1753. [CrossRef] [PubMed]

14. Yu, C.V.; Li, X.F.; Lou, W.Y.; Zhong, M.H. Cross-linked enzyme aggregates of Mung bean epoxide hydrolases: A highly active, stable and recyclable biocatalyst for asymmetric hydrolysis of epoxides. J. Biotechnol. 2013, 166, 12-19. [CrossRef] [PubMed]

15. Zhao, L.; Han, B.; Huang, Z.; Miller, M.; Huang, H.; Malashock, D.S.; Zhu, Z.; Milan, A.; Robertson, D.E.; Weiner, D.P.; et al. Epoxide hydrolase-catalyzed synthesis of chiral 1,2-diols via desymmetrization of meso-epoxides. J. Am. Chem. Soc. 2004, 126, 11156-11157. [CrossRef] [PubMed]

16. Gotor-Fernández, V.; Gotor, V. Aminolysis and ammonolysis of carboxylic acid derivatives. In Asymmetric Organic Synthesis with Enzymes; Gotor, V., Alfonso, I., García-Urdiales, E., Eds.; Wiley-VCH: Weinheim, Germany, 2008; pp. 171-228, ISBN 978-3-527-31825-4.

17. Ghanem, A. Trends in lipase-catalyzed asymmetric access to enantiomerically pure/enriched compounds. Tetrahedron 2007, 63, 1721-1754. [CrossRef]

18. Bornscheuer, U.T.; Kazlauskas, R.J. Hydrolases in Organic Synthesis: Regio- and Stereoselective Biotransformations, 2nd ed.; Wiley-VCH: Weinheim, Germany, 2005; ISBN 978-3-527-60712-9.

19. Mathpati, A.C.; Vyas, V.K.; Bhanage, B.M. Kinetic resolution of 1,2-diols using immobilized Burkholderia cepacea: A combined experimental and molecular dynamics investigation. J. Biotechnol. 2017, 262, 1-10. [CrossRef] [PubMed]

20. Parve, J.; Reile, I.; Aid, T.; Kudrjasova, M.; Muurisepp, A.M.; Vallikivi, I.; Villo, L.; Aav, R.; Pehk, T.; Vares, L.; et al. Lipase-catalyzed stereoresolution of long-chain 1,2-alkanediols: A screening of preferable reaction conditions. J. Mol. Catal. B: Enzym. 2015, 116, 60-69. [CrossRef]

21. Hamberg, A.; Magnusson, A.O.; Hu, F.J.; Hult, K. Selective monoacylation of diols by substrate assisted catalysis in T40A Candida antarctica Lipase B. ChemCatChem 2013, 5, 743-747. [CrossRef]

22. Bencze, L.C.; Paizs, C.; Tosa, M.I.; Irimie, F.D. Sequential use of regio- and stereoselective lipases for the efficient kinetic resolution of racemic 1-(5-phenylfuran-2-yl)ethane-1,2-diols. Tetrahedron Asymmetry 2011, 22, 675-683. [CrossRef]

23. Jew, S.; Roh, E.; Baek, E.; Mireille, L.; Kim, H.; Jeong, B.; Park, M.; Park, H. Asymmetric synthesis of (S)-(+)-etomoxir via enzymatic resolution. Tetrahedron Asymmetry 2000, 11, 3395-3401. [CrossRef]

24. Carmona, J.A.; de Gonzalo, G.; Serrano, I.; Crespo-Peña, A.; Simek, M.; Monge, D.; Fernández, R.; Lassaletta, J.M. Asymmetric organocatalytic synthesis of tertiary azomethyl alcohols: Key intermediates towards azoxy compounds and $\alpha$-hydroxy- $\beta$-amino esters. Org. Biomol. Chem. 2017, 15, 2993-3005. [CrossRef] [PubMed]

25. Serrano, I.; Monge, D.; Álvarez, E.; Fernández, R.; Lassaletta, J.M. Asymmetric organocatalytic synthesis of quaternary $\alpha$-hydroxy phosphonates: En route to $\alpha$-aryl phosphaisoserines. Chem. Commun. 2015, 51, 4077-4080. [CrossRef] [PubMed]

26. Crespo-Peña, A.; Monge, D.; Martín-Zamora, E.; Álvarez, E.; Fernández, R.; Lassaletta, J.M. Asymmetric Formal Carbonyl-Ene Reactions of Formaldehyde tert-Butyl Hydrazone with $\alpha$-Keto Esters: Dual Activation by Bis-urea Catalysts. J. Am. Chem. Soc. 2012, 134, 12912-12915. [CrossRef] [PubMed]

27. Lehn, J.-S.M.; Javed, S.; Hoffman, D.M. Synthesis of zirconium, hafnium, and tantalum complexes with sterically demanding hydrazide ligands. Inorg. Chem. 2007, 46, 993-1000. [CrossRef] [PubMed]

28. Schreiner, P.E.; Wittkopp, A. H-Bonding additives act like Lewis acid catalysts. Org. Lett. 2002, 4, $217-220$. [CrossRef] [PubMed]

29. Crespo-Peña, A. Metodologías y Estrategias Para la Formilación Selectiva de Compuestos Carbonílicos. Ph.D. Thesis, University of Sevilla, Sevilla, Spain, September 2013.

Sample Availability: Samples of the compounds ( \pm )-1-6d and ( \pm )-1-6e are available from the authors. 